\title{
TITLE:
}

\section{$<$ News> DNA Sampling and DNA Analysis of Chimpanzees at Mahale}

AUTHOR(S):

Inoue, Eiji

\section{CITATION:}

Inoue, Eiji. < News> DNA Sampling and DNA Analysis of Chimpanzees at Mahale. Pan Africa News 2005, 12(2): 22-24

\section{ISSUE DATE:}

2005-12

URL:

http://hdl.handle.net/2433/143454

RIGHT:

Copyright (C) Pan Africa News. 


\section{<NEWS>}

\section{DNA Sampling and DNA Analysis of Chimpanzees at Mahale}

Eiji Inoue

Graduate School of Science, Kyoto University

\section{INTRODUCTION}

Improvements in genetic techniques have enabled us to study DNA in wild animals. Until recently, it has been difficult to determine the genetic background of wild animals without capturing them. In many cases, capture disturbs their lives. Accordingly, it is better to use non-invasive methods for analyzing DNA. Genetic research on wild chimpanzees has mostly been conducted by the use of fecal samples ${ }^{1,2}$. Shed or scratched hairs $^{3,4}$, food wadge ${ }^{5}$, and urine ${ }^{6}$ have been also used as DNA samples of primates.

The chimpanzees of the Mahale Mountains National Park have been studied for a long time. Within one well-habituated group, the M group, we know the profiles of many chimpanzees, including age, year of immigration, and mother's name. Consequently, this group is highly suitable for genetic studies. Furthermore, many other groups exist around the Mahale area. If we collect DNA samples from a wide area, the genetic structure of wild chimpanzees will be clarified.

I have collected many materials as DNA samples at Mahale. In this report, I show samples and sampling methods and then present my perspectives on the analyses.

\section{SAMPLES}

I conducted research from August to October 2003 and from October 2004 to October 2005. I collected DNA samples from all of the individuals non-invasively with my colleagues and our research assistants.

When we followed chimpanzees of the M group, we sampled what probably contains cells. We collected feces and urine mainly because it was not difficult to get them while following the chimpanzees. I occasionally 
observed freshly dropped blood on leaves. When individuals were observed to scratch their body and shed their hair, the hairs were collected. Food wadges, which chimpanzees spat out after chewing food, were also collected. Sometimes they licked branches and their saliva remained. Saliva was collected because it probably includes buccal cells. Male chimpanzees discard sperm remaining on their penis after copulation. The sperm samples are probably contaminated with cells from other individuals, but we still collected them. When mothers brought their dead babies, I obtained some fluids from the carcasses. I also collected tissue samples from carcasses of infants after their mothers left them.

It is difficult to observe the chimpanzees of other groups, but we could find the beds of these chimpanzees. I collected their hairs that remained on the beds and feces near or on the beds (Figure 1).

\section{SAMPLING METHODS}

Some of the fecal samples were dried up with silica. Other samples of feces, blood, food wadges, saliva and fluid from carcasses were put into a $0.9 \% \mathrm{NaCl}$ and $1 \mathrm{mM}$ EDTA $\mathrm{Na}_{3}$ solution, to which ethanol was added up to $70 \%$ vol. Ethanol was also added to urine up to $70 \%$ vol. Hair samples were put into the $70 \%$ ethanol environment or kept in a dry condition. Sperm and tissues were also kept in the $70 \%$ ethanol environment.

\section{PERSPECTIVES}

Genetic research on chimpanzees at Mahale has already been conducted by Linda Vigilant of the Max Planck Institute, Germany. Her team analyzed 8 loci of microsatellite DNA in many $M$ group chimpanzees. They extracted DNA from dried feces and succeeded in determining the genotype of many samples. I will cooperate with them and analyze the microsatellite DNA of all $\mathrm{M}$ group members as they did. From the genotype of the $M$ group chimpanzees, we can show the paternity and relatedness of individuals.

Shed hair samples do not always provide enough DNA ${ }^{7}$. If we can get sufficient DNA from shed hairs, we will be able to clarify the genetic structure of wild chimpanzees by microsatellite DNA on autosome, Y

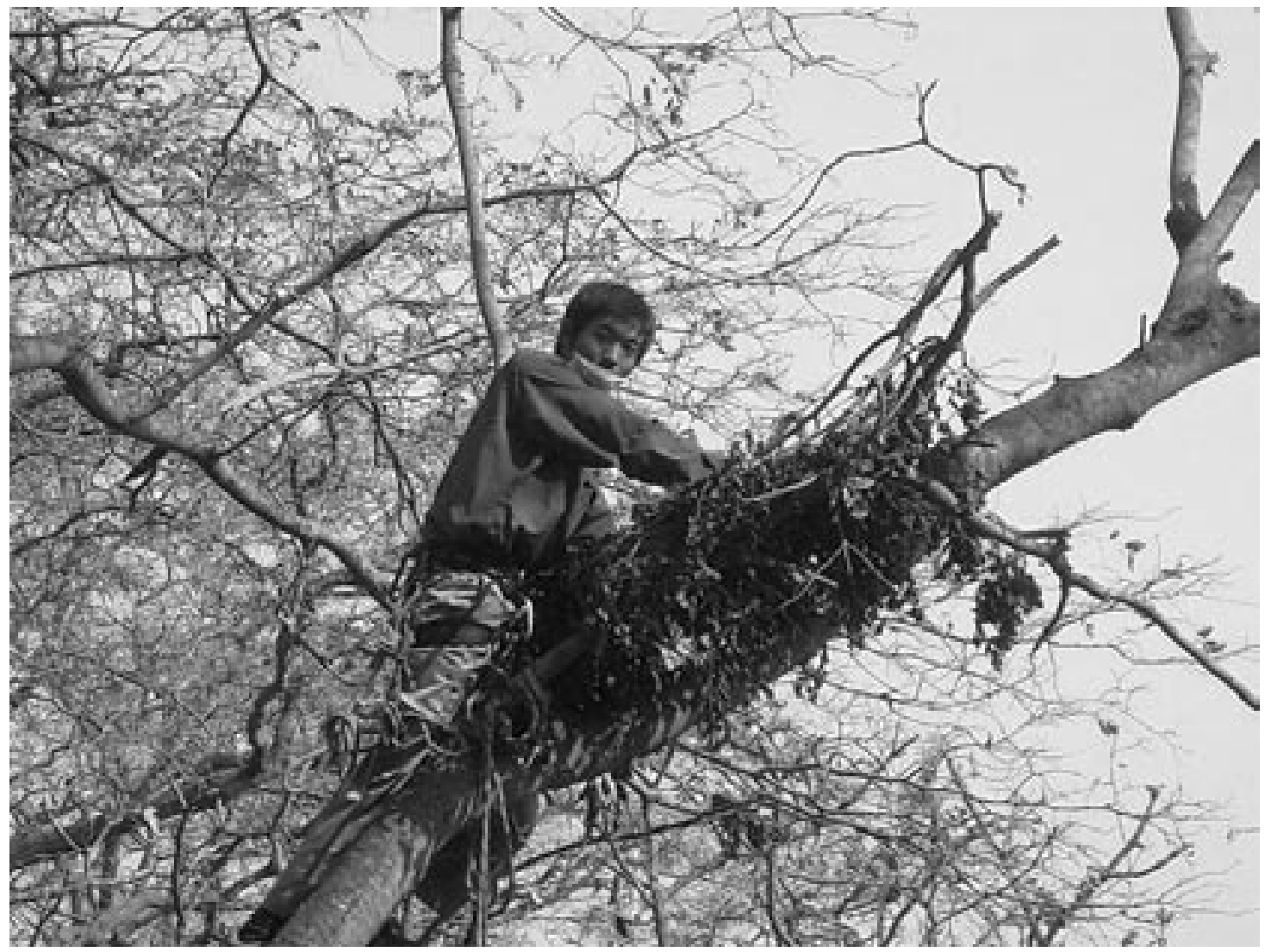

Figure 1. Sampling on the bed of chimpanzee 
chromosome and mitochondrial DNA. Through such analysis, this study will provide important information for conservation of wild chimpanzees.

\section{ACKNOWLEDGEMENTS}

I would like to thank the Tanzania Commission for Science and Technology, the Tanzania Wildlife Research Institute, Tanzania National Park, Mahale Mountains National Park, and the Mahale Mountains Wildlife Research Center for permitting me to conduct this study at Mahale; Osamu Takenaka and Linda Vigilant for their guidance in research methods; and many colleagues and local assistants for cooperation in the field. Financial support was given through the MEXT Grant-in-Aid for Science Research (A1) (\#12375003 and \#16255007 to Toshisada Nishida).

\section{REFERENCES}

1. Vigilant L, Hofreiter M, Siedel $H$ and Boesch C. 2001. Paternity and relatedness in wild chimpanzee communities. Proceedings of the National Academy of Sciences of the USA 98: 12890-128955.
2. Constable JL, Ashley MV, Goodall J and Pusey AE. 2001. Noninvasive paternity assignment in Gombe chimpanzees. Molecular Ecology 10: 1279-1300.

3. Gagneux P, Boesch C and Woodruff DS. 1999. Female reproductive strategies, paternity and community structure in wild West African chimpanzees. Animal Behaviour 57: 19-32.

4. Goldberg TL and Wrangham RW. 1997. Genetic correlates of social behaviour in wild chimpanzees: evidence from mitochondrial DNA. Animal Behaviour 54: 559-570.

5. Hashimoto C, Furuichi T and Takenaka O. 1996. Matrilineal kin relationship and social behavior of wild bonobos (Pan paniscus): Sequencing the D-loop region of mitochondrial DNA. Primates 37: 305-318.

6. Hayakawa S and Takenaka O. 1999. Urine as another potential source for template DNA in polymerase chain reaction (PCR). American Journal of Primatology 48: 299-304.

7. Vigilant L. 2002. Technical challenges in the microsatellite genotyping of a wild chimpanzee population using feces. Evolutionary Anthropology 11 (Suppl 1): 162-165. 